IJM

33,6

648

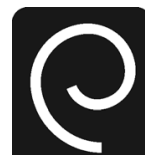

Emerald

International Journal of Manpower Vol. 33 No. 6, 2012 pp. $648-665$

(C) Emerald Group Publishing Limited $0143-7720$

DOI 10.1108/01437721211261804

\title{
Employers' attitudes and actions towards the extension of working lives in Europe
}

\author{
Wieteke S. Conen \\ Department of Law, Economics and Governance, Utrecht University, \\ Utrecht, The Netherlands and \\ Netherlands Interdisciplinary Demographic Institute (NIDI), \\ The Hague, The Netherlands \\ Kène Henkens \\ Netherlands Interdisciplinary Demographic Institute (NIDI), The Hague, \\ The Netherlands and Faculty of Social and Behavioural Sciences, \\ Tilburg University, Tilburg, The Netherlands, and \\ Joop Schippers \\ Department of Law, Economics and Governance, Utrecht University, \\ Utrecht, The Netherlands
}

\begin{abstract}
Purpose - Although policymakers have put great efforts into the promotion of older workers' labour force participation, quantitative empirical knowledge about employers' views towards extension of working lives is limited. The purpose of this paper is to improve the understanding of employers' attitudes and actions towards extension of working lives, by examining recruitment and retention behaviour towards older workers, employers' views on the consequences of an ageing workforce, organisational policies, and what governments can do to extend working lives.

Design/methodology/approach - The authors analyse surveys administered to employers in Denmark, France, Germany, Italy, The Netherlands, Poland, Sweden and the UK in 2009.

Findings - It is found that a minority of employers have applied measures to recruit or retain older workers, and employers rather retain than hire older workers. A considerable share of employers, albeit to different degrees per country, associate the ageing of their staff with a growing gap between labour costs and productivity. Employers expecting a larger gap do not apply more organisational measures to either increase productivity or adjust the cost-productivity balance. Employers may think the cost-productivity issue is partly for governments to solve; employers expecting a larger costproductivity gap consider wage subsidies to be an effective measure to extend working lives.

Originality/value - The paper addresses the employers' perspective, one that is often neglected compared to attitudes and behaviour of older workers themselves and research on institutional arrangements. This paper is also among the first to report on employers' policies and practices from a cross-national perspective.
\end{abstract}

Keywords Denmark, France, Germany, Italy, The Netherlands, Poland, Sweden, United Kingdom, Older workers, Employers, Business policy, Government policy

Paper type Research paper

\section{Introduction}

The ageing of society and the workforce is one of the dominant developments in modern Europe. Although in the short run the current economic crisis enlarges labour pools, in many European regions a decrease in effective labour supply is expected in the long run. Moreover, the ageing of society will cause rising welfare state 
expenditures (European Commission, 2006). Therefore, according to governments and experts, nations and labour markets are in need of higher participation rates of older workers and working lives need to be extended.

Over the last decade, older workers have been gradually working both longer and more (Eurostat, 2010). Despite these upward-sloping participation trends, in most countries employment rates still drop considerably for workers between ages 55 and 59, dropping sharply after age 60 (see Table I). Furthermore, the mean and median age of retirement are often well below the statutory age of retirement - in other words, in most countries early retirement is still rather the rule than the exception. One such exception is Sweden, which is performing relatively well in retaining older workers for the labour market.

Although early retirement may be the rule, older workers' labour force participation rates vary considerably between European countries. There are several explanations for these differences - which are not necessarily mutually exclusive - such as institutional arrangements affecting both supply and demand for older workers and employer and employee attitudes and behaviour towards extending working lives. Vickerstaff et al. (2003) state that any significant change in retirement behaviour will come primarily from policy modifications initiated and undertaken by employers. This paper therefore examines the role played by employers in the recruitment and retention of older workers.

To what extent are employers active players in the current process away from early exit and towards extension of working lives? Earlier research among employers, conducted in the USA and European countries, shows that many employers tend to be biased towards older workers, and there is often a lack of corporate focus on older employees that is reflected in an absence of programmes to retain and retrain them (Barth et al., 1993; Chiu et al., 2001; Guillemard et al., 1996; Henkens, 2005; Taylor and Walker, 1998).

The main questions we will address in this paper are:

- Do employers take action to extend working lives in terms of recruitment and retention of older workers?

Denmark France Germany Italy The Netherlands Poland Sweden UK EU

\begin{tabular}{|c|c|c|c|c|c|c|c|c|}
\hline \multicolumn{9}{|c|}{ Employment rate (2009) } \\
\hline 50-54 years & 84.1 & 80.5 & 79.6 & 69.9 & 82.2 & 68.1 & 84.3 & 79.275 .0 \\
\hline $55-59$ years & 78.5 & 58.5 & 70.2 & 50.7 & 72.4 & 42.6 & 80.3 & $70.6 \quad 60.0$ \\
\hline $60-64$ years & 36.6 & 17.0 & 38.7 & 20.3 & 37.3 & 18.2 & 60.5 & 44.930 .4 \\
\hline \multicolumn{9}{|c|}{ Part-time employment } \\
\hline Ages 50-64 (2009) & 22.6 & 18.8 & 27.2 & 10.6 & 47.3 & 12.1 & 25.4 & 27.919 .6 \\
\hline \multicolumn{9}{|c|}{ Life expectancy at age 65 (2007) } \\
\hline Males & 16.5 & 18.4 & 17.4 & 18.0 & 17.1 & 14.6 & 17.9 & 17.517 .0 \\
\hline Females & 19.2 & 23.0 & 20.7 & 21.8 & 20.7 & 18.9 & 20.8 & 20.220 .5 \\
\hline \multicolumn{9}{|c|}{ Mean age of retirement (2005) } \\
\hline Males & 61.2 & 58.5 & 61.4 & 60.7 & 61.6 & 62.0 & 64.3 & 63.46 \\
\hline Females & 60.7 & 59.1 & 61.1 & 58.8 & 61.4 & 57.4 & 63.0 & 61.9 \\
\hline \multicolumn{9}{|c|}{ Median age of retirement (2005) } \\
\hline Males & 62.2 & 58.8 & 61.6 & 58.4 & 60.5 & 57.0 & 63.9 & 63.8 \\
\hline Females & 60.1 & 58.3 & 59.9 & 57.2 & 59.3 & 55.2 & 63.3 & 60.3 \\
\hline
\end{tabular}

Source: Eurostat (2010)

Employers' attitudes

649

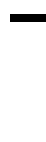


IJM

33,6

650
- What do employers see as possible consequences of an ageing workforce for their own organisation?

- What organisational policies do employers apply to retain older workers?

- And - according to employers - what can governments do to extend working lives?

This paper is among the first to address employers' attitudes and actions with respect to the extension of working lives from a cross-national perspective. We analyse data from comparative surveys carried out among employers in Denmark, France, Germany, Italy, the Netherlands, Poland, Sweden and the UK. These countries cover all types of European welfare state regimes as proposed by Esping-Andersen (1990). Employers from different countries face different labour market and institutional restrictions and policies set out by their governments. This may influence their behaviour on how to deal with the consequences of an ageing workforce. It may also influence their ideas on who is primarily responsible for the consequences of an ageing workforce.

The paper is structured as follows. Section 2 discusses the theoretical background from the employers' perspective on dealing with an ageing workforce. Section 3 describes the data and variables used in this paper. Our results are presented in Section 4, and Section 5 presents our main conclusions and discusses the outcomes.

\section{Theoretical background}

Ageing, productivity and labour costs

According to economic theory, employers' considerations on how to assess the future with an ageing workforce are based on the expected relative benefits and costs of employing workers of different age groups. If wages of older workers exceed their productivity, these are workers representing a potential loss for firms. Examining the relationship between age, labour productivity and labour costs often starts from human capital theory (Becker, 1962; for an overview, see Polachek and Siebert, 1993), which states that investments in human capital boost labour productivity and productivity is positively related to employee remuneration. In principle, people accumulate human capital by training and experience during the whole of their career, which translates into increasing remuneration over time. However, human capital also may depreciate, e.g. because knowledge of older technologies becomes obsolete or because cognitive and physical skills deteriorate. Depreciation of human capital will lead to a decrease in productivity. To balance costs and benefits - from a traditional neo-classical theoretical perspective - remuneration should decline accordingly.

In the late 1970s doubts accumulated about the empirical validity of relationship between age, labour costs and productivity as described by human capital theory (Hutchens, 1989). Lazear (1979) was among the first to address issues such as why do jobs exist where wages increase with seniority, regardless of improvements in productivity. His delayed payment contract theory illustrates how employers may have implicit contracts with their employees regarding the connection between productivity and income over a lifetime: earnings are lower than productivity during the first phase of workers' careers and higher during the second phase. Such contracts function as an incentive for employees to put enough effort into their work to obtain the higher wages at the end of the implicit contract period. An employee who shirks runs the risk of being fired before the wage premium is obtained. Hence delayed compensation works 
as an incentive for employees to work harder, stay longer with the organisation and transfer human capital to younger generations of workers.

Skirbekk (2008) provides an overview of how age impacts the various physical and cognitive skills of workers, and how this translates into changes in productivity potential. Many studies find that productivity tends to reach a peak in mid-career, roughly somewhere between ages 30 and 45 (e.g. Lehman, 1953; Ilmakunnas et al., 2004; Jones, 2005). Productivity depends on both physical and cognitive skills, and the impact of age on both types of skills has been studied extensively. Looking at physical skills, the biological process of internal depreciation is irreversible, although inter-individual differences are considerable. In general, a decline sets in from age 30 onwards, but because this is a very slow process and because most organs have overcapacity, most people only signal problems from age 60 onwards. Starting from age 45, many people notice that their physical condition is deteriorating. Older workers tend to have longer recovery periods. Physical skills obsolescence is particularly important in manual jobs and often related to unskilled jobs (Hidding et al., 2004; Nauta et al., 2004). In modern societies, cognitive skills have gained significance and have become a strong predictor of productivity. Although it is generally accepted that physical abilities decline with age, cognitive functioning has more ambiguous outcomes. Cognitive functioning is often divided into fluid and crystallised cognitive functioning (Horn and Catell, 1967; Baltes et al., 1999). Fluid cognitive skills refer to the process of acquiring information, like mental agility, mental arithmetic, solving problems and making quick connections. The quality is genetic and comes with high inter-individual variation. These skills decrease with age. Crystallised cognitive skills refer to knowledge and experience that is embodied in a person after years of practice, learning and repeating. These skills are found to increase with age. In addition, older workers often compensate lower fluid cognitive skills by using adaptation strategies (Baltes et al., 1999). Until recently, crystallised skills have received little attention in age-related cognitive research.

Although the age-productivity profile is hard to observe and generalise, we expect employers to have some idea about the relative productivity of older workers as compared to other age groups. Such ideas may be based for instance on employers' observations of personnel over time and comparisons with other staff members. Employers also know the context and the extent to which older workers are able to keep up with job requirements when they age. This is related to what Phelps (1972) calls "previous statistical experience": information on how certain categories of employees tend to behave and develop. Many employers use these statistical experiences to formulate expectations regarding the future productivity of employees who belong to a particular category.

\section{Policies to extend working lives}

Most European employers realise that an ageing workforce may result in future labour market problems (Van Dalen et al., 2009). Given this awareness and the attempts of European governments to address topics such as raising the retirement age and stimulating older workers' labour force participation, employers may anticipate and thus apply measures that will facilitate an extension of working lives. Organisational policies towards extension of working lives are based on the profitability of this action, therefore labour costs and productivity can be considered to be important determinants. The logical thing to do for employers is thus to take measures aimed at reducing the labour cost-productivity gap, by, first, enhancing productivity, second,
Employers' attitudes

651 
IJM

33,6

652 balancing costs and productivity or third, reducing labour costs. This means employers may take measures aimed at maintaining workers' human capital to prevent an eventual decline in productivity (e.g. training plans for older workers) or aimed at bringing back the wage-productivity balance (e.g. by means of demotion). Training plans and demotion, when applied thoughtfully, are often mentioned as a potential solution to expected negative consequences of an ageing workforce (Hall and Isabella, 1985; European Commission, 2006). In order to reduce labour costs, a possible solution to face negative consequences of an ageing workforce is to let go of "expensive" staff members, such as older workers enjoying relatively high seniority-based wages or older workers with decreased productivity and no remuneration adjustments. Early retirement schemes can therefore be considered a way to reduce labour costs. If employers do not see any options to reduce the gap, they may turn to finally, accommodative measures to prevent a further decline and preserve workers' current productivity. In this category we find policies such as decreasing the workload for older workers, extra leave for older workers or reduction of working time before retirement.

The state of the economy may affect employers' attitudes and behaviour towards older workers. Employers in countries with low unemployment rates (like the Netherlands, at about 4-5 per cent) are more likely to recruit and retain older workers and to apply measures stressing the importance of extending careers than employers in countries with high unemployment rates (like France, Sweden and Poland, with unemployment rates between 8 and 10 per cent).

\section{Methods}

We used data from comparative surveys carried out among employers in Denmark, France, Germany, Italy, the Netherlands, Poland and Sweden. Participating research institutes in the ASPA project carried out the data collection. ASPA is an acronym for "activating senior potential in ageing Europe", a research project funded as part of the EU Seventh Framework programme under the Socio-Economic Sciences and Humanities theme. Data collection took place from March to November 2009. The total number of completed questionnaires amounts to 5,822, of which 609 are from Denmark, 500 from France, 892 from Germany, 770 from Italy, 1,077 from the Netherlands, 1,037 from Poland, 525 from Sweden and 412 from the UK (see Appendix). The overall response rate was 23 per cent and ranged from 7 to 53 per cent for the various countries. This is lower than the average response rate for individual surveys but in line with the rate generally found in corporate surveys. In Europe and the USA, response rates have been found to be 20-30 per cent at most (see Brewster et al., 1994; Kalleberg et al., 1996).

The questionnaires used in the different countries were identical, and were translated from English to the national languages. The national questionnaires were checked by the overall co-ordinator on international comparability before the fieldwork started.

The surveys were sent to directors, owners and heads of HR departments. Interview techniques used differed between countries, depending on what was perceived to be the best way to address respondents in a specific country. Denmark did computer-assisted web interviewing; Germany, the Netherlands and Sweden used paper and pencil; and France, Italy, Poland and the UK did computer-assisted telephone interviewing.

For all countries we drew a stratified sample on the sector and size characteristics of the establishments. In the analyses at the national level we weighted the data afterwards to account for the sampling design, to ensure the observations were 
representative for the population of employers. Weights were constructed according to the population of establishments from national statistics bureaus and corrected for sector and size of the establishment. To present results at the pooled level, we pooled the data for all eight countries - including the national weighting factors - and constructed a new weighting factor that takes the net sample size of the different countries into account. Otherwise, Dutch and Polish employers $(N>1,000)$ would influence results more than French and Swedish employers $(N \approx 500)$.

\section{Results}

\section{Retention and recruitment behaviour}

The first results we present, show - for all countries - that employers rather retain than recruit older workers (Table II). At the pooled level, 12-13 per cent of European employers recruit older workers or employees who already retired during a personnel shortage; 27 per cent encourage older workers to continue working until retirement age. The retirement age seems to be a normative barrier in all countries, because very few employers stimulate working beyond the statutory retirement age by either recruiting or retaining older workers. For instance, 27 per cent of European employers stimulate working until the statutory retirement age, whilst 13 per cent stimulate working beyond the retirement age. Another more general feature seems to be that none of the measures to recruit or retain older workers have been applied by a majority of employers. On average, only 2 per cent of employers apply all four measures we asked for to either recruit or retain older workers and 63 per cent indicate neither recruiting nor retaining older workers.

The results also show some differences between countries. Polish employers display the most activating behaviour: 5 per cent apply all measures asked for and 39 per cent neither recruits nor retains older workers. Recruitment of retirees is generally low, but Poland is an exception in this respect, as recruitment of retirees is rather common there. Polish and French employers report most often stimulating older employees to continue working until the official retirement age. This may find its origin in the fact that French and Polish employees retire relatively early. Italian and Dutch employers

The

Pooled Denmark France Germany Italy Netherlands Poland Sweden UK

Stimulate working until

retirement age

Stimulate working

beyond retirement age

Recruit older workers

Recruit employees who

already retired

All of above

recruitment/retention

measures

None of above

recruitment/retention

measures

27

$27 \quad 34$

$13 \quad 18$

$12 \quad 16$

13

8

10

40

26

11

8

8
11

7

22

7
22

5

2

17

3

$$
2
$$

1

3

0

0

$\begin{array}{lll}63 & 57 & 54\end{array}$

56

82

75
Employers' attitudes

653

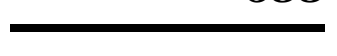

Source: ASPA Employers Survey (2009)

Table II.

Recruitment and retention behaviour towards older workers $(\%)$ 
IJM

33,6

654 exhibit the least activating behaviour, with considerably lower levels of recruitment and retention of older workers than in other countries.

Although cross-national differences are clearly present, an important finding is that recruitment and retention levels of older workers all over Europe are rather low in general. This seems to indicate that, on a more aggregated level, employers may be reluctant to actively promote older workers' employment by either hiring them or encouraging them to continue working until retirement age - let alone beyond retirement age.

\section{Age, productivity and labour costs}

Employers' behaviour towards older workers may stem from various underlying reasons, such as the expected consequences of an ageing staff for their own organisation. Table III sets out how employers expect an ageing workforce will affect productivity and labour costs. With respect to the relationship between ageing and productivity the results show that in all countries a majority of employers state that productivity as such is not affected by an ageing workforce. However, a substantial minority (28 per cent) expects productivity to decrease; this is the highest in Germany, where 38 per cent of employers expect a productivity decline, and at 15 per cent lowest in the UK. On the other hand, on average 10 per cent of employers expect productivity to increase.

A positive effect of an ageing workforce can be seen in the second part of the table, presenting employers' expectations regarding the knowledge base. Roughly half of employers expect an increase in the knowledge base, and $<10$ per cent expect a decline. When combining employers' opinions on the development of productivity and on the knowledge base one may conclude that from the employers' perspective an increasing knowledge base does not seem to directly translate into higher productivity. Even though human capital increases, the additional human capital is not necessarily relevant from the perspective of productivity.

The third part of the table presents the expectations regarding the influence of ageing on labour costs. Lazear's theory on implicit contracts contends that it is a decline in productivity which is behind a lack of support for working longer. It is in the

Consequences

Pooled Denmark France Germany Italy The Netherlands Poland Sweden UK

\section{Labour productivity}

Table III.

Expected consequences of an ageing personnel structure for own organisation $(\%)$

\section{Same}

(Strong) decline
(Strong) increase 10

Same $\quad 62$

(Strong) decline 28

Knowledge base

(Strong) increase 42

Same

(Strong) decline 9

Labour costs

(Strong) increase 44

$\begin{array}{rrrr}10 & 7 & 10 & 14 \\ 71 & 64 & 54 & 62 \\ 19 & 28 & 36 & 25 \\ 47 & 53 & 46 & 38 \\ 44 & 42 & 43 & 52 \\ 9 & 5 & 11 & 10 \\ & & & \\ 33 & 51 & 48 & 49 \\ 61 & 43 & 51 & 48 \\ 6 & 6 & 1 & 3\end{array}$

Note: Based on the ques the effect on [...]?"

Source: ASPA Employers Survey (2009) 
nature of the contract that workers are paid more than they are "worth" at higher ages, even when productivity remains the same. The table offers some support for this notion. For the pooled sample we established that almost half of employers expect an increase in labour costs[1]. There are, however, large differences between countries. In Poland, Denmark and the UK up to one-third of employers expect labour costs to increase. In Sweden, Germany, Italy and France roughly half of employers expect costs to increase. Employers in the Netherlands are at the other end of the spectrum: here 75 per cent think labour costs will increase due to an ageing workforce. Only very few employers expect a decline in labour costs, with Poland leading at 10 per cent.

The combination of expectations on labour costs and productivity translate into expectations on the development of the labour cost-productivity gap[2] with an ageing workforce. We combined the answers given in Table III with respect to labour costs and labour productivity to establish whether employers perceive a cost-productivity gap as a result of an ageing workforce. For instance, when an employer expects an increase in labour costs accompanied by a decrease in productivity, this indicates an increasing cost-productivity gap. The same holds for a situation in which productivity is expected to stay the same but labour costs are expected to increase; this will imply an increase of the cost-productivity gap. Figure 1 shows the results of this categorisation.

Overall, about half of employers expect the wage-productivity gap to increase with an ageing workforce (51 per cent). The table shows large differences between countries. Dutch employers are most sceptical when it comes to expectations about older workers; 75 per cent expect the wage-productivity gap to increase as the workforce ages. In Poland and the UK the wage-productivity gap is less of an issue; in those countries about one-third of employers think the wage-productivity gap will increase.

\section{Organisational policies}

An important question is how these employers' expectations regarding the wageproductivity gap translate into organisational policies. Are policies focused on bringing costs and benefits of older workers into equilibrium? Even if in the past employers' behaviour did not indicate an emphasis on activating behaviour with respect to recruiting and retaining older workers, maybe current policies do show a path towards activating behaviour and thus towards extension of working lives?

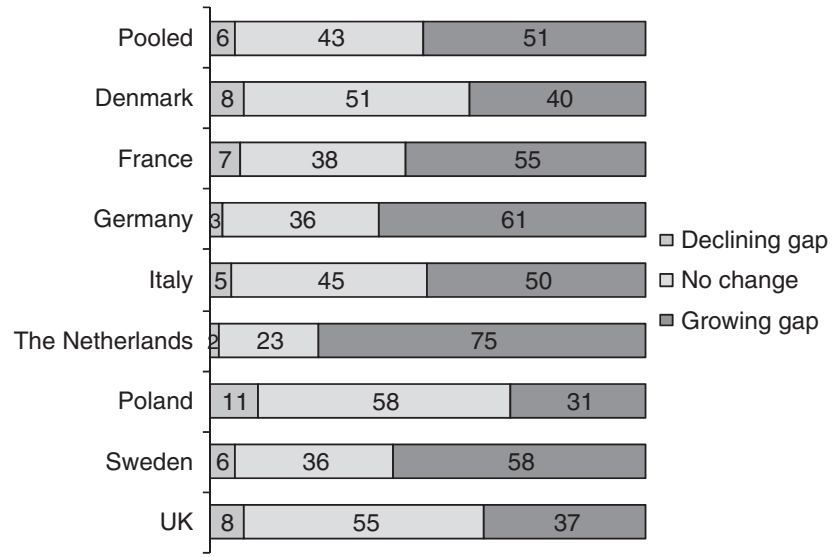

Source: ASPA Employers Survey (2009)
Employers' attitudes

655 
IJM

33,6

656
To answer such questions, we presented employers with a list of measures and asked them to indicate whether their organisation was currently applying them. The list was based on earlier research into age-conscious personnel policies (e.g. Remery et al., 2003)[3]. As mentioned in Section 2, organisational policies are categorised into four categories. The first category aims to enhance productivity (training plans for older workers), the second can be considered as a way to reduce labour costs (early retirement), the third focuses on balancing costs and productivity (for instance by reducing both tasks and salary, or demotion) and the fourth category is a group of "accommodative measures" (such as possibilities for extra leave or decreasing older workers' workload). Table IV presents an overview of the share of employers from different countries that apply different measures.

In general, employers most frequently implemented flexible working hours as a measure aimed at accommodating the needs of older workers (35 per cent). Organisations in several countries, like the Netherlands and Denmark, do take various measures, such as reducing the workload or offering possibilities for extra leave.

Lifelong learning is often perceived to be the key solution to enhance productivity at older ages (European Commission, 2006; OECD, 2006). The share of organisations offering training programmes for older staff varies highly between countries, but is on average about one-quarter. Relatively many UK employers report having training plans for older workers. French employers also applied training plans relatively often; this may stem from the inter-sectoral agreement on "employee lifelong access to training" adopted in France, which promotes training among experienced workers and was signed in 2003 by the French social partners (OECD, 2006).

Early retirement schemes, which can be considered a way to reduce labour costs for employers, are implemented by 17 per cent of European employers. In the Netherlands and Poland about one-third of employers apply early retirement schemes. It is obvious

The

Pooled Denmark France Germany Italy Netherlands Poland Sweden UK

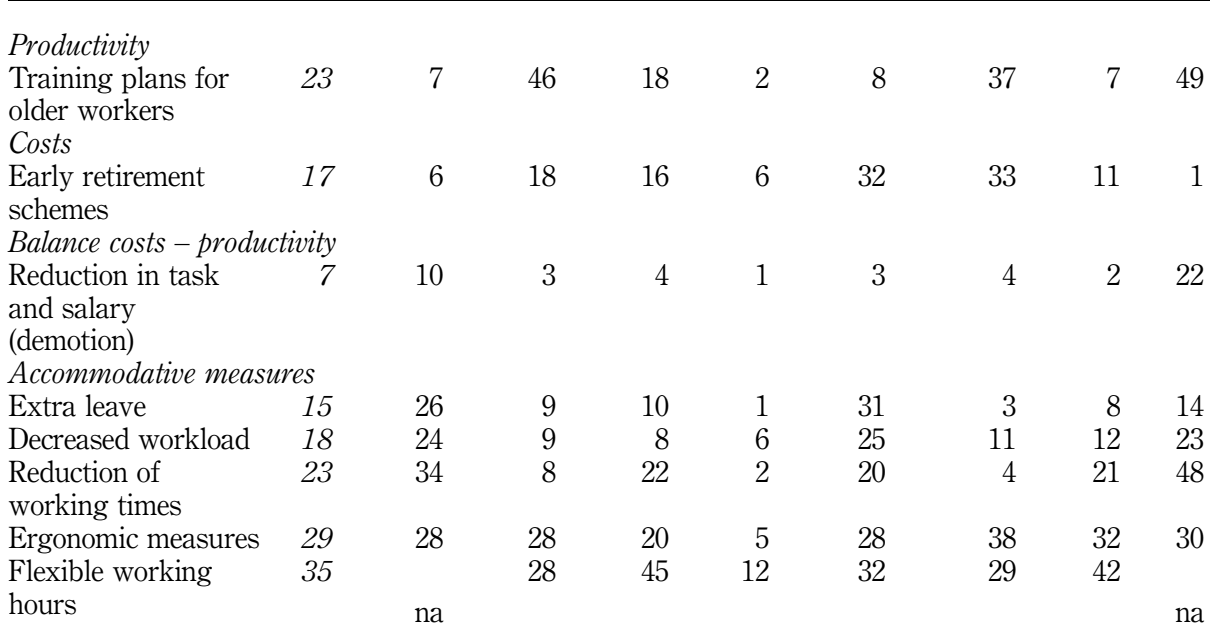

Table IV.

Policies implemented by employers in order to

retain older personnel (\%) Source: ASPA Employers Survey (2009) 
that higher levels of early retirement schemes do not stimulate the extension of working lives, and the higher levels of Dutch and Polish employers do not reflect a focus on career extension.

Measures aimed at reviewing older workers' productivity and remuneration, such as reduction in task and salary (demotion), were found to be almost absent, with the exception of the UK, where 22 per cent of employers implemented this policy. The results from Table IV thus show that in most countries training plans and demotion although often suggested by scientists and policy makers to tackle negative consequences of an ageing workforce - are not embraced by employers.

In Table $\mathrm{V}$ we present the results of a multivariate analysis conducted to examine employers' policies towards older workers in more detail. We looked at four types of policy measures:

(1) training plans for older workers (to increase labour productivity);

(2) early retirement schemes (to reduce labour costs);

\begin{tabular}{|c|c|c|c|c|c|c|c|c|}
\hline & $\begin{array}{l}\text { Training } \mathrm{p} \\
\text { older } \mathrm{w}\end{array}$ & $\begin{array}{l}\text { lans for } \\
\text { rkers }\end{array}$ & $\begin{array}{l}\text { Early reti } \\
\text { schem }\end{array}$ & $\begin{array}{l}\text { rement } \\
\text { hes }\end{array}$ & $\begin{array}{r}\text { Reduction } \\
\text { and sal }\end{array}$ & $\begin{array}{l}\text { of tasks } \\
\text { lary }\end{array}$ & $\begin{array}{r}\text { Reduc } \\
\text { work }\end{array}$ & $\begin{array}{l}\text { ion of } \\
\text { load }\end{array}$ \\
\hline & Odds ratio & $z$-value & Odds ratio & $z$-value & Odds ratio & $z$-value & Odds rati & $z$-value \\
\hline $\begin{array}{l}\text { Expected wage- } \\
\text { productivity gap }\end{array}$ & 0.96 & -0.81 & $1.17 * *$ & 3.16 & 1.03 & 0.36 & $1.12^{*}$ & 2.10 \\
\hline Sector of industry & (public sect & $r=$ refere & nce category & & & & & \\
\hline $\begin{array}{l}\text { Industrial and } \\
\text { construction* }\end{array}$ & $0.78^{*}$ & -2.44 & $1.52^{* * *}$ & 4.33 & 1.01 & 0.07 & $0.81 *$ & -2.16 \\
\hline $\begin{array}{l}\text { Services and } \\
\text { trade* }\end{array}$ & 0.90 & -1.00 & 1.13 & 1.16 & 1.32 & 1.86 & $0.69 * *$ & -3.42 \\
\hline $\begin{array}{l}\text { Size of the } \\
\text { organisation } \\
\text { (logarithm) } \\
\text { Skills level of work }\end{array}$ & $1.30 * *$ & 9.49 & $1.59^{* *}$ & 16.99 & $1.36^{* * *}$ & 8.83 & $1.28^{* * *}$ & 9.55 \\
\hline $\begin{array}{l}\text { Share of } \\
\text { employees in } \\
\text { high-skilled jobs }\end{array}$ & $1.50^{* *}$ & 2.67 & 1.18 & 1.15 & 0.91 & -0.39 & 1.14 & 0.85 \\
\hline $\begin{array}{l}\text { Share of } \\
\text { employees in } \\
\text { unskilled jobs }\end{array}$ & 0.74 & -1.90 & $0.67^{*}$ & -2.55 & 0.68 & -1.61 & 1.19 & 1.11 \\
\hline $\begin{array}{l}\text { Share of older } \\
\text { workers }\end{array}$ & $1.95^{* *}$ & 2.81 & $5.32 * *$ & 7.36 & 1.44 & 1.01 & 1.38 & 1.35 \\
\hline Countries (Swe & $n=$ referenc & ategory) & & & & & & \\
\hline Denmark & 1.03 & 0.17 & 0.7 & -1.52 & $7.08^{* * *}$ & 7.27 & $4.06^{* *}$ & 8.26 \\
\hline rance & $11.30 *$ & 11.75 & & 2.44 & 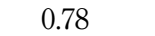 & -0.47 & 0.91 & -0.37 \\
\hline & & & & & & 0. & 0.7 & -1.83 \\
\hline \#y & 0. & -5.53 & & -3.21 & 0.2 & -3.10 & $0.58^{* * *}$ & -2.75 \\
\hline The Netherlands & $1.45^{*}$ & 2.09 & $6.60 * *$ & 12.62 & $2.09 * *$ & 2.70 & $4.04 * *$ & 8.66 \\
\hline Poland & $6.06^{* * *}$ & 10.90 & $4.41 * *$ & 10.02 & 0.89 & -0.35 & 0.92 & $-0.43 \mathrm{~s}$ \\
\hline & $11.73^{* *}$ & 12.97 & $0.06^{* * *}$ & -4.85 & $9.56^{* * *}$ & 8.05 & $3.20 * *$ & 6.08 \\
\hline $\begin{array}{l}\text { Pseudo } R^{2} \\
N\end{array}$ & $\begin{array}{r}0.1 \\
5,03\end{array}$ & & $\begin{array}{r}0.24 \\
5,03\end{array}$ & & $\begin{array}{r}0.16 \\
5,03 ?\end{array}$ & & & \\
\hline
\end{tabular}

Notes: *Significant at $p \leqslant 0.05 ; * *$ significant at $p \leqslant 0.01$

Source: ASPA Employers Survey (2009)
Employers' attitudes

657 
IJM

33,6

658
(3) reduction of tasks and salary, or demotion (to balance productivity and costs); and

(4) reduction of workload (same as demotion, but without remuneration adjustments).

We tested whether personnel policies undertaken by employers are related to the expected wage-productivity gap. In the model we included country dummy variables as well as structural characteristics of the organisation, such as sector, age structure, skills level and size as control variables. In Table $\mathrm{V}$ the odds ratio represents the ratio of the probability of employers applying a measure to the probability they will not.

Do employers who expect a larger wage-productivity gap take measures more often to bridge this gap than employers who are less concerned with this gap? Table $\mathrm{V}$ shows that employers expecting a larger gap do not more often attempt to enhance productivity through training or to balance cost and productivity by means of demotion. They do, however, apply early retirement schemes more often, as well as accommodative measures like reduction of workload. With respect to the latter there may be a causality problem: employers who implement measures to reduce the workload may be perceiving a larger gap.

The results show sector differences. In industries and construction employers implement fewer training plans and more early retirement schemes than in the public sector. In addition, the services and trade sector is more involved in policies such as demotion and less in the reduction of workload than the public sector. The results also point at the importance of the size of organisations, as the existence of a policy for older workers is positively related to size. It may be that larger organisations have more opportunities to pursue policies and benefit more from economies of scale, as is the case with the implementation of training plans. High-skilled organisations implement more training plans. Organisations with a large share of older workers are more inclined to opt for early retirement schemes as well as for training plans and policies aimed at a reduction of workload. This last result suggests that the ageing of the workforce stimulates organisations to develop personnel policies in this area.

\section{Governmental policies}

In the past, European institutions and national governments have been the main drivers in creating awareness about the necessity to extend working lives and set targets on the labour force participation of seniors (European Commission, 2002, 2006). With these earlier initiatives in mind, we presented employers with a list of possible measures governments can take to promote older workers' employment. We asked employers whether they considered these measures potentially effective or ineffective in improving older workers' labour force participation. Their answers are summarised in Table VI.

Almost three-quarters of employers - up to 92 per cent in Denmark - favoured measures that allow for some kind of part-time retirement or bridge employment. Such measures may help older workers to carry on, even though they may no longer be as healthy or productive as they used to be. If older workers can retire on a part-time basis, employers will not have to pay any longer for all or part of non-productive hours or days. In France and Italy the expectations regarding the effectiveness of incentives to combine work and retirement are somewhat lower; this probably has to do with the fact that in those countries the combination of work and retirement is regulated by law - it was forbidden in France until 2003. The second measure is the promotion of 
The

Pooled Denmark France Germany Italy Netherlands Poland Sweden UK
Employers' attitudes
Incentives to combine

work retirement

Promoting lifelong

learning

Wage subsidies for

older workers

Lowering early

retirement benefits

Laws preventing age

discrimination

Media campaigns

combating negative

stereotypes

$\begin{array}{lllllllll}74 & 92 & 55 & 80 & 63 & 78 & 69 & 68 & - \\ 62 & 62 & 74 & 79 & 83 & 34 & 51 & 59 & - \\ 58 & 64 & 45 & 68 & 36 & 71 & 67 & 58 & - \\ 43 & 62 & 39 & 37 & 58 & 39 & 35 & 28 & - \\ 36 & 36 & 34 & 17 & 61 & 32 & 48 & 27 & - \\ 35 & 36 & 28 & 32 & 62 & 27 & 28 & 29 & -\end{array}$

Source: ASPA Employers Survey (2009)

Governmental measures to retain older workers, percentage (very) effective

lifelong learning, which may enhance productivity; this measure is considered most effective in Italy. This is remarkable, since Italian employers hardly indicated having some kind of training plan for older workers. On the other hand, maybe employers think they cannot or should not be responsible for lifelong learning, and therefore believe the government has to take responsibility for this. The third most effective measure according to employers are wage subsidies for older workers, which may "compensate" organisations; this measure is considered especially effective in the Netherlands, Germany and Poland. Relatively often, in Italy employers consider laws preventing age discrimination and the combat against negative stereotypes to be effective measures. In the Netherlands and the UK such legislation already exists.

In Table VII we present the results of a multivariate analysis carried out to examine the perceived effectiveness of governmental policies. We looked at three types of governmental policies related to lessening the wage-productivity gap by either reducing costs or increasing productivity:

(1) incentives to combine work and retirement (to balance productivity and costs);

(2) promotion of lifelong learning (to keep up labour productivity); and

(3) wage subsidies for older workers (to reduce costs).

We tested whether the perceived effectiveness of those measures is related to the expected wage-productivity gap. In the model we included country dummy variables as well as structural characteristics of the organisation, such as sector, age structure, skills level and size as control variables. The table shows that the expected wageproductivity gap is positively related to the perceived effectiveness of wage subsidies for older workers. Employers expecting an increasing wage-productivity gap are not more prone to consider the combination of work and retirement or the promotion of lifelong learning to be an effective governmental policy.

The results show some sector differences. In industries and construction, employers consider all three governmental policies less effective than in the public sector; in services and trade the promotion of lifelong learning is considered less effective than in the public sector. With respect to size, the results show that large organisations 
IJM

33,6

Combine work Promote lifelong Wage subsidies for retirement learning older workers

Odds ratio $z$-value Odds ratio $z$-value Odds ratio $z$-value

660

\begin{tabular}{llrlrlr} 
Expected wage-productivity gap & 1.06 & 1.60 & 0.95 & -1.30 & $1.10^{* * *}$ & 2.58 \\
$\begin{array}{l}\text { Sector of industry (public sector = reference category) } \\
\text { Industrial and construction* }\end{array}$ & $0.83^{*}$ & -2.46 & $0.72^{* *}$ & -4.35 & $0.86^{* *}$ & -2.09 \\
Services and trade* & 0.91 & -1.19 & $0.81^{* *}$ & -2.75 & 0.94 & -0.86 \\
Size of the organisation (logarithm) & 1.02 & 0.92 & $1.19^{* *}$ & 8.98 & $0.91^{* *}$ & -5.12 \\
Skills level of workers & & & & & & \\
Share of employees in high-skilled jobs & 1.03 & 0.30 & $1.51^{* *}$ & 3.69 & 0.85 & -1.44 \\
Share of employees in unskilled jobs & 0.97 & -0.27 & $0.67^{* *}$ & -3.50 & 1.03 & 0.25 \\
Share of older workers & 1.02 & 0.11 & 0.87 & -0.83 & 0.75 & -1.67 \\
Countries (Sweden = reference category) & & & & & & \\
Denmark & $3.40^{* *}$ & 9.62 & $1.51^{* *}$ & 3.35 & $1.49^{* *}$ & 3.31 \\
Germany & $1.41^{* *}$ & 2.89 & $3.02^{* *}$ & 9.26 & 1.23 & 1.80 \\
Italy & $0.53^{* *}$ & -5.31 & $3.26^{* *}$ & 9.86 & $0.32^{* *}$ & -9.78 \\
The Netherlands & $1.73^{* *}$ & 4.69 & $0.63^{* *}$ & -4.08 & $2.00^{* *}$ & 6.20 \\
Poland & 0.91 & -0.86 & $0.80^{*}$ & -1.97 & $1.81^{* *}$ & 5.37 \\
Pseudo $R^{2}$ & \multicolumn{2}{c}{0.04} & & 0.06 & & \multicolumn{2}{c}{0.04} & \\
$N$ & 4,525 & & 4,525 & & 4,525 &
\end{tabular}

Table VII.

Perceived effectiveness governmental policies (ordered logistic regression analysis)
Notes: *Significant at $p \leqslant 0.05$; **significant at $p \leqslant 0.01$

Source: ASPA employers survey (2009)

consider the promotion of lifelong learning to be an effective policy more often than small organisations, while wage subsidies are perceived to be an effective measure especially by smaller organisations. The perceived effectiveness of the promotion of lifelong learning is positively related to the share of high-skilled workers in an organisation.

\section{Conclusions and discussion}

This paper addressed for main questions: Do European employers take action to extend working lives in terms of recruitment and retention of older workers? What do employers see as possible consequences of an ageing workforce for their own organisation? What organisational policies do European employers apply to retain older workers? And - according to employers - what can governments do to extend working lives?

Both recruitment and retention levels of older workers are rather low in all of the countries included in this study, and employers' actions to extend working lives have a stronger focus on retention than on recruitment of older workers. There also seems to be a normative barrier in employers' behaviour: recruitment and retention beyond the statutory age of retirement is not applied by many employers. Our results show important outcomes with respect to perceived changes in costs and benefits as the workforce ages, as a substantial number of employers foresee an increasing wageproductivity gap. This perceived gap may explain employers' reluctance to hire and stimulate older workers to continue working until or even beyond the existing retirement age.

So far, organisational policies do not seem to be aimed at tackling the wage-productivity gap. Although demotion and lifelong learning are suggested by scientists and policy makers as a way to bridge the gap between labour costs and 
productivity, the enthusiasm for actual implementation of these measures is not shared by employers. Except for the UK, employers do not apply demotion of older workers to balance pay and productivity. Also, additional training to prevent or counter a decline in productivity is given by only a minority of employers. Demotion and training are not implemented more often by employers expecting a larger wage-productivity gap. On the contrary, early retirement schemes and reduction of workload without remuneration adjustments are applied more often by employers expecting a larger pay-productivity gap.

Our study is among the first to address employers' views on governmental policies concerning older workers and extending working life. The most effective governmental measure to increase labour force participation of older workers - according to employers - are incentives to combine work and retirement. A preference for such a combination suggests there is room for older workers to extend their working lives inside organisations, albeit in an adjusted form. Phased retirement is one way to combine work and retirement, and may also include - in the wording of the TLM approach (Klosse and Schippers, 2008) - preventive transitions. Preventive transitions are a form of career mobility that prevents older workers from getting stuck in a job where they gradually lose their productivity. Another possibility is bridge employment. Bridge employment means that older workers work in any form between their career jobs and full retirement, for instance by taking a part-time job or other temporary employment prior to definitive retirement, within the same occupation or in the same position, or in a completely different job. In the literature bridge employment is described as becoming more common, and its occurrence is expected to further increase (Cahill et al., 2006; Johnson et al., 2009).

The second and third most effective governmental measures to increase labour force participation of older workers are the promotion of lifelong learning and wage subsidies. The larger the labour cost-productivity gap employers expect, the more often they consider wage subsidies to be an effective measure to increase the labour force participation of older workers. This suggests that employers expect governments to partly facilitate the process of bridging the gap between pay and productivity. Interestingly, the effectiveness of wage subsidies is rated high by employers in small organisations, which are much less involved in policy initiatives to improve the productivity of older workers and may be more dependent on government support.

Our study shows that although policy makers have put great efforts into the promotion of older workers' labour participation, relatively few employers are behaving in a way that actively supports a trend towards working longer. The international comparison shows that the lack of action from employers to activate senior potential is not a matter of just one specific country. This does not imply that European employers show a uniform pattern in their attitudes and behaviour towards older workers: outcomes do not follow a "European way" and are not distinguishable by type of welfare state, and national contexts do turn out to be highly relevant. Attitudes and behaviour of Swedish employers, for example, differ considerably from those of their Danish colleagues (both belonging to Esping-Andersen's, 1990 socialdemocratic welfare state), and equally large variation exists between German and French employers (both belonging to the continental/conservative welfare state type). Any solutions along the lines of "one European way" of stimulating extension of working lives and increasing labour force participation of older workers therefore seem to be - at least at this point in time - not necessarily viable. The results are not distinguishable by economic climate either. In earlier research, Conen et al. (2011)
Employers' attitudes

661 
IJM

33,6

662

showed for the Netherlands that changes in the demand for workers affect employers' recruitment and retention behaviour towards older workers. Although unemployment rates vary highly between the countries under study, we do not find a divide between employers showing more activating behaviour towards their older workers in countries with low unemployment rates than in countries with high unemployment rates.

There are several noteworthy contributions of this study to the existing literature. First, the paper addresses employers' perspective on the extension of working lives, a perspective that is often neglected when compared to research on attitudes and behaviour of older workers themselves and to research on institutional arrangements affecting both supply and demand for older workers. Another contribution of the paper is that it is among the first to report on employers' policies and practices from countries from all parts of Europe and from all types of European welfare states. The cross-national dimension is important, as it provides information on whether employers' attitudes and actions towards older workers are either a national phenomenon or can be more widely found among European employers.

The study does have a number of limitations. One limitation is that, although the dataset is sizeable, it is difficult to assess to what extent the national samples are representative of the population of interest due to the varying response rates. A low response rate can give rise to sampling bias if the non-response is unequally distributed. However, there is no minimum for an "acceptable" response rate: research suggests that in many cases surveys with varying response rates yield results that are statistically indistinguishable (Keeter et al., 2006).

Another limitation is its reliance on self-reported behaviour. Respondents may be reporting that they recruit or retain older workers or apply policies in accordance with a dominant organisational or national policy even though they are not really complying. Future studies may combine self-reported behaviour with direct measures of hiring and retention behaviour.

In this survey study we found European employers to be little involved in extending older workers' careers, and the dominant consequence of the ageing of the workforce is perceived to be a growing gap between labour costs and productivity. A logical next question is whether these perceived consequences are accurate, or whether employers underestimate or overestimate the development of labour costs and productivity as the workforce ages. Future researchers may want to combine employers' perceptions about developments in labour costs and productivity and actual measures within organisations.

\section{Notes}

1. Labour costs may consist of both direct wages and additional labour costs (such as extra leave or sickness absenteeism). Although "wages" and "labour costs" are not the same, in the economic literature it is more common to talk about a wage-productivity gap than about a labour cost-productivity gap. We therefore use "wages" and "labour costs" interchangeably.

2. The categories of the expected labour cost-productivity gap were established as follows: "1" - (strong) increase in productivity and (strong) decrease in labour costs; "2" - labour productivity stays the same and (strong) decrease in labour costs or (strong) increase in labour productivity and labour costs stay the same; " 3 " - (strong) decrease in both labour productivity and labour costs or labour productivity and labour costs both stay the same or both labour productivity and labour costs (strongly) increase; "4" - labour productivity (strongly) decreases and labour costs stay the same OR labour productivity stays the same 
and labour costs (strongly) increase; "5" labour productivity (strongly) decreases and labour costs (strongly) increase.

3. In earlier studies we allowed employers to also come up with "other" measures that were not included in the list of suggested measures. All additional measures mentioned by employers could easily be classified under the heading of the measures already included in the list.

\section{References}

ASPA Employers Survey (2009), Netherlands Interdisciplinary Demographic Institute, ASPA Employers Survey, The Hague.

Baltes, P.B., Staudinger, U.M. and Lindenberger, U. (1999), "Lifespan psychology: theory and application to intellectual functioning", Annual Review of Psychology, Vol. 50, pp. 471-507.

Barth, M.C., McNaught, W. and Rizzi, P. (1993), "Corporations and the ageing workforce", in Mirvis, P.H. (Ed.), Building the Competitive Workforce: Investing in Human Capital for Corporate Success, Wiley and Sons, New York, NY, pp. 156-200.

Becker, G.S. (1962), "Investment in human capital: a theoretical analysis", Journal of Political Economy, Vol. 70 No. 5, pp. 9-49.

Brewster, C., Hegewisch, A., Mayne, L. and Tregaskis, O. (1994), "Methodology of the price waterhouse Cranfield project", in Brewster, C. and Hegewisch, A. (Eds), Policy and Practice in European Human Resource Management, Routledge, London, pp. 230-45.

Cahill, K.E., Giandrea, M.D. and Quinn, J.F. (2006), "Retirement patterns from career employment", The Gerontologist, Vol. 46 No. 4, pp. 514-23.

Chiu, W.C.K., Chan, A.W., Snape, E. and Redman, T. (2001), "Age stereotypes and discriminatory attitudes towards older workers: an East-West comparison", Human Relations, Vol. 54 No. 5, pp. 629-61.

Conen, W.S., Henkens, K. and Schippers, J.J. (2011), “Are employers changing their behavior toward older workers? An analysis of employers' surveys 2000-2009”, Journal of Aging \& Social Policy, Vol. 23 No. 2, pp. 141-58.

Esping-Andersen, G. (1990), The Three Worlds of Welfare Capitalism, Polity Press, Oxford.

European Commission (2002), Report Requested by Stockholm European Council: "Increasing Labour Force Participation and Promoting Active Ageing", European Commission, Brussels.

European Commission (2006), The Demographic Future of Europe - From Challenge to Opportunity, European Commission, Brussels.

Eurostat (2010), Labour Force Survey, Eurostat Database, Luxembourg.

Guillemard, A., Taylor, P. and Walker, A. (1996), "Managing an ageing workforce in Britain and France", Geneva Papers on Risk and Insurance-Issues and Practice, Vol. 21 No. 4, pp. 478-501.

Hall, D.T. and Isabella, L.A. (1985), "Downward movement and career development", Organizational Dynamics, Vol. 14 No. 1, pp. 5-23.

Henkens, K. (2005), "Stereotyping older workers and retirement: the managers' point of view", Canadian Journal on Aging, Vol. 24 No. 4, pp. 353-66.

Hidding, R., Jong, A.de, Krestin, M., Severijnen, T., Tromp, H., Vermeulen, M., Visman, L. and Zuijdervliet, J. (2004), De oudere werknemer. Omgaan met vergrijzing in de organisatie, STECR, Hoofddorp.

Horn, J.L. and Catell, R.B. (1967), "Age differences in fluid and crystallized intelligence”, Acta Psychologica, Vol. 26 No. 2, pp. 107-29.

Hutchens, R.M. (1989), "Seniority, wages and productivity: a turbulent decade", Journal of Economic Perspectives, Vol. 3 No. 4, pp. 49-64.
Employers' attitudes

663 
IJM

33,6

664
Ilmakunnas, P., Maliranta, M. and Vainiomäki, J. (2004), "The role of employer and employee characteristics for plant productivity", Journal of Productivity Analysis, Vol. 21 No. 3, pp. 249-76.

Johnson, R.W., Kawachi, J. and Lewis, E.K. (2009), Older Workers On The Move: Recareering in Later Life, AARP, Public Policy Institute, Washington, DC.

Jones, B. (2005), “Age and great invention”, Working Paper Series No. 11359, National Bureau of Economic Research, Cambridge, MA.

Kalleberg, A.L., Knoke, D., Marsden, P. and Spaeth, J. (1996), Organizations in America: Analyzing their structures and Human Resource Practices, Sage Publications, London.

Keeter, S., Kennedy, C., Dimock, M., Best, J. and Craighill, P. (2006), "Gauging the impact of growing nonresponse on estimates from a national RDD telephone survey", Public Opinion Quarterly, Vol. 70 No. 5, pp. 759-79.

Klosse, S. and Schippers, J. (2008), "The integration of older workers in European labour markets: between macro desires and micro reality", in Pennings, F., Konijn, Y. and Veldman, A. (Eds), Social Responsibility in Labour Relations, Kluwer Law International, Alphen aan den Rijn, pp. 391-411.

Lazear, E.P. (1979), "Why is there mandatory retirement?", Journal of Political Economy, Vol. 87 No. 6, pp. 1261-74.

Lehman, H.C. (1953), Age and Achievement, Princeton University Press, Princeton, NJ.

Nauta, A., De Bruin, M.R. and Cremer, R. (2004), De mythe doorbroken. Gezondheid en inzetbaarheid oudere werknemers, TNO Arbeid, Hoofddorp.

OECD (2006), Live Longer, Work Longer, OECD Publishing, Paris.

Phelps, E.S. (1972), "The statistical theory of racism and sexism", The American Economic Review, Vol. 62 No. 4, pp. 659-61.

Polachek, S.W. and Siebert, W.S. (1993), The Economics of Earnings, Cambridge University Press, Cambridge, MA.

Remery, C., Henkens, K., Schippers, J.J. and Ekamper, P. (2003), "Managing an ageing workforce and a tight labor market: views held by Dutch employers", Population Research and Policy Review, Vol. 22 No. 1, pp. 21-40.

Skirbekk, V. (2008), “Age and productivity potential: a new approach based on ability levels and industry-wide task demand", Population and Development Review, Vol. 34, Supplement, pp. 191-207.

Taylor, P. and Walker, A. (1998), "Employers and older workers: attitudes and employment practices”, Ageing and Society, Vol. 18 No. 6, pp. 641-58.

Van Dalen, H., Henkens, K. and Schippers, J. (2009), "Dealing with an ageing labour force: what do European Employers expect and do?”, Journal of European Social Policy, Vol. 19 No. 1, pp. 47-60.

Vickerstaff, S., Cox, J. and Keen, L. (2003), "Employers and the management of retirement", Social Policy \& Administration, Vol. 37 No. 3, pp. 271-87.

\section{Further reading}

Antikainen, A. (2001), "Is lifelong learning becoming a reality? The case of Finland from a comparative perspective", European Journal of Education, Vol. 36 No. 3, pp. 379-94.

Fouarge, D. and Schils, T. (2008), Training Older Workers: Does It Help Make Them Work Longer?, OSA-Publication, A230, Tilburg. 
Appendix

\begin{tabular}{lrrrr}
\hline Country & $N$ & Response rate $\%$ & Method & \\
\hline & 609 & & & \\
Denmark & 500 & 28 & CAWI & $\mathbf{6 6 5}$ \\
France & 892 & 7 & CATI & PAPI \\
Germany & 770 & 11 & CATI & Table AI. \\
Italy & 1,077 & 17 & PAPI & CATI \\
The Netherlands & 1,037 & 23 & PAPI & Descriptive charecteristics \\
Poland & 525 & 53 & CATI & of samples used \\
Sweden & 412 & 22 & & \\
UK & & & &
\end{tabular}

\begin{abstract}
About the authors
Wieteke S. Conen studied Economics at Utrecht University and is currently working as a $\mathrm{PhD}$ student at Utrecht University and the Netherlands Interdisciplinary Demographic Institute (NIDI). Her research interest covers employers' behaviour towards older workers. Wieteke S. Conen is the corresponding author and can be contacted at:w.s.conen@uu.nl

Kène Henkens is a Sociologist and Head of the Social Demography Department of the Netherlands Interdisciplinary Demographic Institute (NIDI). He is currently Professor of Sociology of Retirement at the University of Amsterdam and is affiliated with Netspar. He has published extensively on issues regarding the labour supply in an ageing workforce. His main research interest lies in the area of an ageing workforce and retirement.

Joop Schippers is Professor of Labour Economics and the Economics of Equal Opportunity at Utrecht University. He has published a series of books and articles on male-female wage differences, human capital investments, labour market flexibility and organisational behaviour with respect to women and older workers.
\end{abstract}

To purchase reprints of this article please e-mail: reprints@emeraldinsight.com Or visit our web site for further details: www.emeraldinsight.com/reprints 